\title{
Polymerase Chain Reaction for the Detection of Mycobacterium leprae
}

\author{
By RUDY A. HARTSKEERL, MADELEINE Y. L. DE WIT AND \\ PAUL R. KLATSER* \\ N.H. Swellengrebel Laboratory of Tropical Hygiene, Royal Tropical Institute, Meibergdreef 39 , \\ 1105-AZ Amsterdam Z.O., The Netherlands
}

(Received 7 March 1989; revised 8 May 1989; accepted 24 May 1989)

\begin{abstract}
A polymerase chain reaction (PCR) using heat-stable Taq polymerase is described for the specific detection of Mycobacterium leprae, the causative agent of leprosy. A set of primers was selected on the basis of the nucleotide sequence of a gene encoding the $36 \mathrm{kDa}$ antigen of $M$. leprae. With this set of primers in the PCR, M. leprae could be detected specifically with a detection limit approximating one bacterium. This PCR appears to meet the criteria of specificity and sensitivity required for a useful tool in epidemiology and eventually for the control of leprosy.
\end{abstract}

\section{INTRODUCTION}

Leprosy is still a major health problem in many parts of the world. It is one of the major disabling diseases and imposes a considerable burden in terms of morbidity and social stigma. The lack of methods to identify Mycobacterium leprae quickly and specifically has hampered research into the distribution and spread of the bacillus (World Health Organization, 1988). A sensitive and specific method for the detection of $M$. leprae would add an unbiased criterion to the available means of diagnosis and it might allow diagnosis of leprosy at a very early stage before the appearance of clinical signs. Furthermore, studies on leprosy infection could be envisaged which would give information on cardinal issues such as the sources of infection, the number of infected individuals, the clustering of infectious reservoirs, the risk of infection and disease and the effect of prophylactic treatment within a population.

$M$. leprae cannot be cultured in vitro. It can be cultured in modest quantities in animals (e.g. armadillos) after experimental infection, which is expensive and time-consuming (Kirchheimer \& Storrs, 1971). Mycobacteria can be visualized by staining followed by microscopy, but this is not specific for $M$. leprae. Current available serological tests show a relatively low sensitivity, which, in combination with the low prevalence of leprosy, limits their application to early case finding and detection of infection (Fine et al., 1988). Even when satisfactory immunodetection is achieved, the problems of detecting colonization and infectivity of carriers before the immune response is initiated will remain. Monoclonal antibodies offer a quick and precise identification of $M$. leprae (Kolk et al., 1985) and DNA probes offer the same, rapid and reliable detection of bacteria (Shoemaker et al., 1985). These methods do not, however, meet the required criterion of sensitivity. Nevertheless, DNA probes offer a route to the more sensitive detection and identification of bacterial DNA, for example of $M$. leprae DNA in clinical samples, through the application of the polymerase chain reaction (PCR) using $M$. leprae specific primers. This method is based on the amplification of characteristic DNA sequences (Saiki et al., 1985). PCR has been shown to be very sensitive and, using appropriate primers, specific and has already been applied successfully to the diagnosis of genetic disorders and to the detection of viruses (Saiki et al., 1985; Kogan et al., 1987; Wong et al, 1987; Ou et al., 1988; Shibata et al., 1988).

Abbreviation: PCR, polymerase chain reaction. 
Here we describe the development of a PCR for the specific and sensitive detection of $M$. leprae DNA which may have potential use as a tool in the epidemiology and control of leprosy.

\section{METHODS}

Bacterial strains and growth conditions. The bacterial strains used are listed in Table 1. M. leprae was isolated from spleen tissue of an experimentally infected armadillo (Dasypus novemcinctus Linn.) as recommended by the World Health Organization (1980). Armadillo liver tissue was obtained from animals experimentally infected with different isolates of patient-derived $M$. leprae. Cultivable mycobacteria were grown in Sauton liquid medium, heat-killed $\left(10 \mathrm{~min}\right.$ at $80^{\circ} \mathrm{C}$ ) and harvested by centrifugation. Clinical isolates of other bacteria (see Table 1 ), grown on blood-agar plates, were kindly provided by Dr R. J. van Ketel (Department of Medical Microbiology, Academic Medical Hospital, Amsterdam, The Netherlands).

Preparation of chromosomal DNA. DNA was isolated by a modification of the method described by Okanishi \& Manome (1980) for the isolation of DNA from Streptomyces. Bacteria were washed twice with Tris-buffered saline/EDTA (150 mM-NaCl, $100 \mathrm{mM}-\mathrm{Tris} / \mathrm{HCl}, \mathrm{pH} 8 \cdot 0$, and $10 \mathrm{mM}$-EDTA) and resuspended in the same buffer (4 mg wet weight $\left.\mathrm{ml}^{-1}\right)$, containing lytic enzyme $\mathrm{Ll}\left(12 \mathrm{mg} \mathrm{ml}^{-1}\right.$; BDH) and lysozyme $\left(2 \mathrm{mg} \mathrm{ml}^{-1}\right)$. After incubation for $18 \mathrm{~h}$ at $37^{\circ} \mathrm{C}$, proteinase $\mathrm{K}$ and SDS were added to final concentrations of $1 \mathrm{mg} \mathrm{m}$ m $^{-1}$ and $1 \%(\mathrm{w} / \mathrm{v})$, respectively, and incubation was continued for $2 \mathrm{~h}$ at $60^{\circ} \mathrm{C}$. SDS was then added to a final concentration of $3.5 \%(\mathrm{w} / \mathrm{v})$ and the mixture was incubated for another $2 \mathrm{~h}$ at $60^{\circ} \mathrm{C}$.

The DNA solution was extracted twice with phenol and chloroform and precipitated with ethanol (Maniatis $e t$ al., 1982). After washing with $70 \%(\mathrm{v} / \mathrm{v})$ ethanol, the DNA was air-dried and redissolved in $10 \mathrm{~mm}-\mathrm{Tris} / \mathrm{HCl}, \mathrm{pH}$ 8.0, $1 \mathrm{~mm}$-EDTA to a concentration of $20 \mu \mathrm{g} \mathrm{ml}^{-1}$.

DNA from human peripheral blood lymphocytes and from homogenized armadillo liver ( $2 \mathrm{~min}$ at 2000 r.p.m. in $100 \mathrm{mM}$-Tris/HCl, $\mathrm{pH} 8 \cdot 0,10 \mathrm{~mm}$-EDTA) was prepared in the same way as the bacterial DNA. Concentrations of DNA were determined spectrophotometrically at $260 \mathrm{~nm}$ and concentrations were verified by comparing the intensities of bands after electrophoresis of various amounts of DNA on $0.7 \%(\mathrm{w} / \mathrm{v})$ agarose gels with bands of known quantities of DNA.

Southern blot hybridization. Southern blotting (Southern, 1975) and hybridization were done basically as described by van Eys et al. (1988). Denatured DNA was blotted onto Zeta-probe nylon membranes (Bio-Rad) according to the manufacturer's instructions. A $1.0 \mathrm{~kb} E c o \mathrm{RI}$ fragment comprising the gene encoding the $36 \mathrm{kDa}$ antigen of $M$. leprae (hereafter referred to as the $36 \mathrm{~K}$ gene) (J. E. R. Thole and others, unpublished results) was used as a DNA probe. The DNA was labelled using a DNA digoxigenin-dUTP labelling and detection kit (Boehringer Mannheim) and added at a concentration of $10 \mathrm{ng}(\mathrm{ml} \mathrm{hybridization} \mathrm{mix})^{-1}$. Pre-hybridization and hybridization were done at $60^{\circ} \mathrm{C}$ for $1 \mathrm{~h}$ and $16 \mathrm{~h}$ respectively. Membranes were washed sequentially in $2 \times \mathrm{SSC}$, $0.1 \times \mathrm{SSC}, 0.1 \%(\mathrm{w} / \mathrm{v}) \mathrm{SDS}$ and $0.01 \times \mathrm{SSC}, 0.1 \%(\mathrm{w} / \mathrm{v}) \mathrm{SDS}$ for $30 \mathrm{~min}$ each at $60^{\circ} \mathrm{C}(1 \times \mathrm{SSC}$ is $0.15 \mathrm{M}-\mathrm{NaCl}$, 0.015 M-trisodium citrate, $\mathrm{pH} 7.0$ ) (Maniatis et al., 1982).

Oligonucleotides. We compared the DNA sequences of the genes encoding the $65 \mathrm{kDa}$ antigen of $M$. leprae (Mehra et al., 1986) and Mycobacterium bovis BCG/Mycobacterium tuberculosis (Thole et al., 1987; Shinnick et al., 1987) (these genes will be subsequently referred to as the $65 \mathrm{~K}$ genes). We then selected two homologous regions (for M. leprae, bp 1365-1385 and bp 1551-1568, and for $M$. bovis BCG, bp 1734-1754 and bp 1920-1937) separated by a DNA segment of 166 bp on each gene (numbering of bp according to Mehra et al., 1986 and Thole et al., 1987, respectively). Oligonucleotides P1 (CTCAAGGAGCGCAAGCACCG) and P2 (TTGAAGGCGATCTGCTT) are complementary to the + and - strands of these homologous sequences. Oligonucleotides S13 (CTCCACCTGGACCGGCGAT) and S62 (GACTAGCCTGCCAAGTCG) are complementary to the + and - strands of sequences positioned $494 \mathrm{bp}$ apart on the gene encoding the $36 \mathrm{~K}$ antigen of $M$. leprae (de Wit \& Klatser, 1988; J. E. R. Thole and others, unpublished results). Oligonucleotides were kindly synthesized by $\mathbf{H}$. M. Hodemaekers, National Institute for Public Health and Environmental Hygiene, Bilthoven, The Netherlands, on a Gene Assembler (Pharmacia). Oligonucleotides were purified by thin layer chromatography using HPTLC Kieselgel 60F254 plates (Merck, FRG) and an elution buffer consisting of $35 \%(\mathrm{v} / \mathrm{v}) \mathrm{NH}_{4} \mathrm{OH}, 55 \%(\mathrm{v} / \mathrm{v})$ propanol and $10 \%(\mathrm{v} / \mathrm{v}) \mathrm{H}_{2} \mathrm{O}$.

PCR. The PCR with the heat-stable DNA-polymerase from Thermus aquaticus (Taq; Perkin Elmer) was done essentially as recommended by the manufacturer. Briefly, 2.5 units Taq enzyme were added to $100 \mu$ lof a solution of $50 \mathrm{~mm}-\mathrm{NaCl}, 9 \mathrm{mM}-\mathrm{MgCl}_{2}, 10 \mathrm{mM}-\mathrm{Tris} / \mathrm{HCl}, 0.2 \mathrm{mg} \mathrm{ml}^{-1} \mathrm{BSA}, \mathrm{pH} 9.6$ containing $1 \mathrm{~mm}$ of each of the deoxynucleotides dATP, dCTP, dGTP and dTTP (Pharmacia) and, unless otherwise indicated, $100 \mathrm{ng}$ DNA and $30 \mathrm{ng}$ of each primer. PCRs were performed in a PCR-processor (Bio-med) using 45 cycles as follows: 2 min denaturation at $94{ }^{\circ} \mathrm{C}, 2 \mathrm{~min}$ annealing at $55^{\circ} \mathrm{C}$ and $3 \mathrm{~min}$ primer-extension at $72^{\circ} \mathrm{C}$. After the 45 th cycle the extension reaction was continued for another $12 \mathrm{~min}$ at $72^{\circ} \mathrm{C}$. Samples of $20 \mu \mathrm{l}$ of the reaction mixtures were loaded onto $2 \%$ agarose gels containing $0.5 \mu \mathrm{g} \mathrm{ml}^{-1}$ ethidium bromide for electrophoresis (Maniatis et al., 1982). HaeIII-digested $\phi \mathrm{X} 174(\mathrm{RF})$ DNA (New England Biolabs) was used as a molecular size marker. 
Table 1. Bacterial species and strains

Strain

8346

5544

8063

8316

515

ATCC 6841

ATCC 25220

8270

ATCC 15985

1012

Armadillo isolate

219

3445

ATCC 14468

4514

H37Rv

ATCC 25949

Clinical isolate

Clinical isolate

Clinical isolate

Clinical isolate

Clinical isolate

Clinical isolate

Clinical isolate
Species

Armadillo derived mycobacteria

Mycobacterium africanum

Mycobacterium avium

Mycobacterium bovis

Mycobacterium chelonei

Mycobacterium duvalii

Mycobacterium fortuitum

Mycobacterium gastri

Mycobacterium gordonae

Mycobacterium intracellulare

Mycobacterium kansasii

Mycobacterium leprae

'Mycobacterium lufu'

Mycobacterium scrofulaceum

Mycobacterium smegmatis

Mycobacterium tuberculosis

Mycobacterium tuberculosis

Mycobacterium vaccae

Streptococcus pneumoniae

Escherichia coli

Haemophilus influenzae

Klebsiella pneumoniae

Legionella pneumophila

Pseudomonas aeruginosa

Staphylococcus aureus
Source/origin

F. Portaels (Portaels \& Pattyn, 1982)

RIVM*

F. Portaels

RIVM

F. Portaels

S. R. Pattyn

ATCC $†$

ATCC

RIVM

ATCC

RIVM

This laboratory

RIVM

RIVM

ATCC

RIVM

RIVM

ATCC

R. J. van Ketel

R. J. van Ketel

R. J. van Ketel

R. J. van Ketel

R. J. van Ketel

R. J. van Ketel

R. J. van Ketel

* National Institute of Public Health and Environmental Hygiene, Bilthoven, The Netherlands.

$\dagger$ American Type Culture Collection.

\section{RESULTS AND DISCUSSION}

\section{Selection of primers}

Two sets of primers were selected on the basis of established nucleotide sequences of the $36 \mathrm{~K}$ and $65 \mathrm{~K}$ genes to specifically detect $M$. leprae through amplification of characteristic DNA sequences.

Primers S13 and S62 were derived from the nucleotide sequence of the $36 \mathrm{~K}$ gene of $M$. leprae (J. E. R. Thole and others, unpublished results). The $36 \mathrm{kDa}$ antigen contains specific as well as cross-reactive epitopes (de Wit \& Klatser, 1988). Consistent with this we found that the gene probably present in one copy in the genome - hybridized moderately to weakly with DNA preparations from other mycobacteria. It is therefore likely that a large proportion of the gene consists of $M$. leprae-specific nucleotide sequences (Hartskeerl et al., 1988; unpublished observations).

Oligonucleotides $\mathrm{P} 1$ and $\mathrm{P} 2$ were based on two homologous regions within the $65 \mathrm{~K}$ genes of $M$. leprae and $M$. bovis BCG (Mehra et al., 1986; Thole et al., 1987). The $65 \mathrm{kDa}$ antigen is a heat-shock protein present in most, if not all, bacteria as well as in eukaryotic cells (Shinnick $e t$ al., 1988; Thole et al., 1988; Thole, 1988). Because of the wide occurrence of the $65 \mathrm{~K}$ gene, the use of these primers in the PCR was expected to provide a positive internal control for the reaction.

PCR experiments indeed revealed amplification of target DNA of a large number of species with primers $\mathrm{P} 1$ and $\mathrm{P} 2$, and the specific amplification of $M$. leprae DNA with primers S13 and S62 (Fig. 1).

\section{Specificity of the PCR}

Primers S13 and S62 were tested in the PCR with target DNA purified from 25 different species. Primers $\mathrm{P} 1$ and $\mathrm{P} 2$ were added as an internal control for the reaction. The use of primers $\mathrm{S} 13$ and $\mathrm{S} 62$ resulted in the specific amplification of $M$. leprae DNA (Fig. $1 a$ ). No detectable 


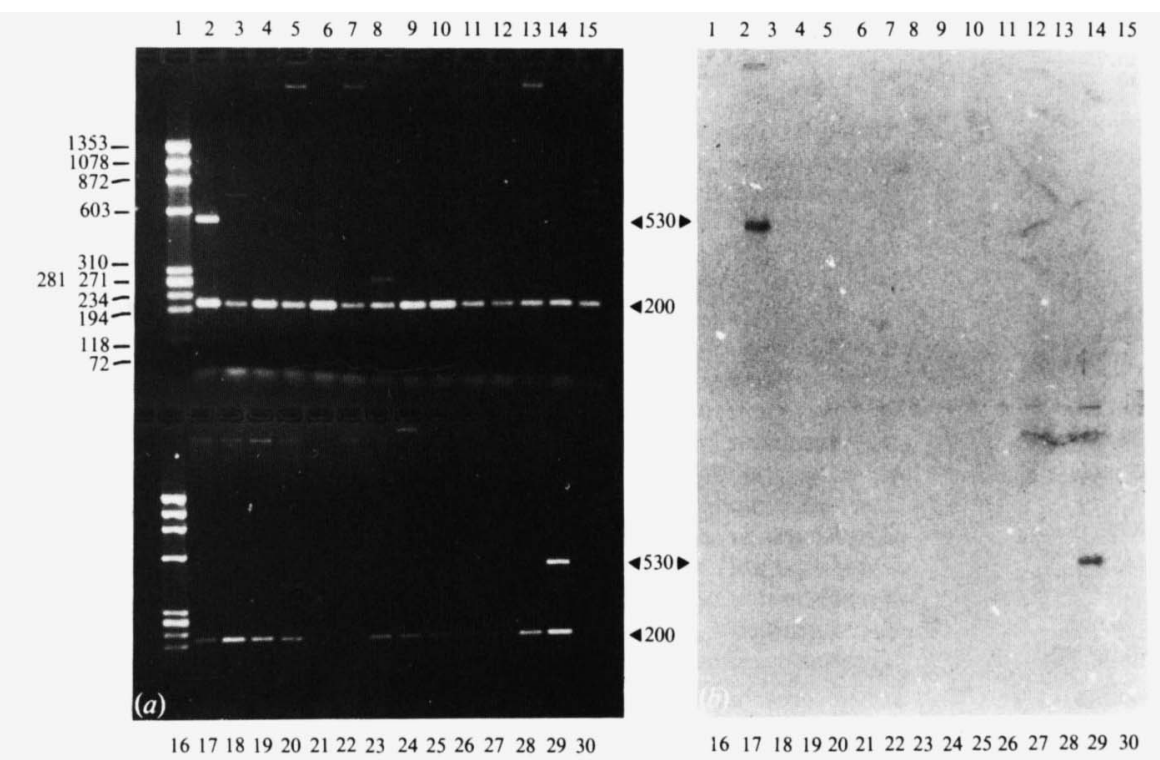

Fig. 1. Specificity of PCR. PCR was performed with a combination of primer pairs S13/S62 and P1/P2. PCR was performed as described in Methods, with $150 \mathrm{ng}$ of each of the primers P1 and P2 also added to the reaction mixture. (a) Analysis of amplified DNA by electrophoresis on a $\%(\mathrm{w} / \mathrm{v})$ agarose gel; (b) Southern blot analysis of the agarose gel with a $1 \mathrm{~kb}$ EcoRI fragment comprising the $36 \mathrm{~K}$ gene of $M$. leprae as a probe. PCR was performed with target DNA from: $M$. leprae (lanes 2 and 29 ), $M$. vaccae (lane 3), $M$. tuberculosis (lane 4), $M$. bovis (lane 5), armadillo derived mycobacteria (lane 6), $M$. avium (lane 7), $M$. smegmatis (lane 8), $M$. scrofulaceum (lane 9), $M$. gastri (lane 10), M. gordonae (lane 11), $M$. kansasii (lane 12), ' $M$. lufu' (lane 13), $M$. chelonei (lane 14), $M$. duvalii (lane 15), $M$. fortuitum (lane 17), $M$. intracellulare (lane 18), $M$. africanum (lane 19), $M$. tuberculosis H37Rv (lane 20), human lymphocytes (lane 21), P. aeruginosa (lane 22), $\boldsymbol{H}$. influenzae (lane 23), E. coli (lane 24), Staph. aureus (lane 25), K. pneumoniae (lane 26), L. pneumophila (lane 27), Strep. pneumoniae (lane 28) and no DNA (negative control, lane 30 ). Lanes 1 and 16 contained molecular size markers. Numbers at left and right indicate sizes in bp.

amplification occurred with DNA from other species, including closely related mycobacteria. The size of the amplified fragment was $530 \mathrm{bp}$, which is in agreement with the position of the primers in the $36 \mathrm{~K}$ gene. The specificity of the PCR was confirmed by a Southern blot of this gel with the $36 \mathrm{~K}$ gene as a DNA probe, on which a band at the $530 \mathrm{bp}$ position was visible only in the samples containing $M$. leprae DNA (Fig. $1 b$ ). No bands were visible in samples in which DNA from other sources was used in the PCR. PCR mixtures also contained primers P1 and P2, which resulted in the generation of an additional fragment of about $200 \mathrm{bp}$ in all samples (Fig. $1 b$ ). The amplification of this fragment virtually rules out the possibility of unsatisfactory reaction conditions. Hence, the lack of detectable DNA processing with primers S13 and S62 in samples containing DNA from sources other than $M$. leprae was likely due to absence of homology between the primers and the target DNA. The sources of target DNA tested included pathogenic and non-pathogenic mycobacteria and other bacteria, as well as human DNA. Because the PCR with primers S13 and S62 gave no amplification of DNA from a number of bacteria which may be present in human derived samples, nor of human DNA under the conditions described, this method is potentially useful for the detection of $M$. leprae in human samples.

The use of primers $\mathrm{P} 1$ and P2 in the PCR resulted in the amplification of a single $200 \mathrm{bp}$ fragment of target DNA from most of the species tested (Fig. 1 a). Additional bands on agarose gels were observed in only a few samples (Fig. $1 a$, lanes $2,8,13,15$ and 20). Since these amplified fragments were larger than $200 \mathrm{bp}$ in size, and were not detected when annealing was done at temperatures higher than $55^{\circ} \mathrm{C}$ (result not shown), they are probably the result of 'mispriming' outside the selected template (Mullis \& Faloona, 1987). The varying intensities of the DNA 

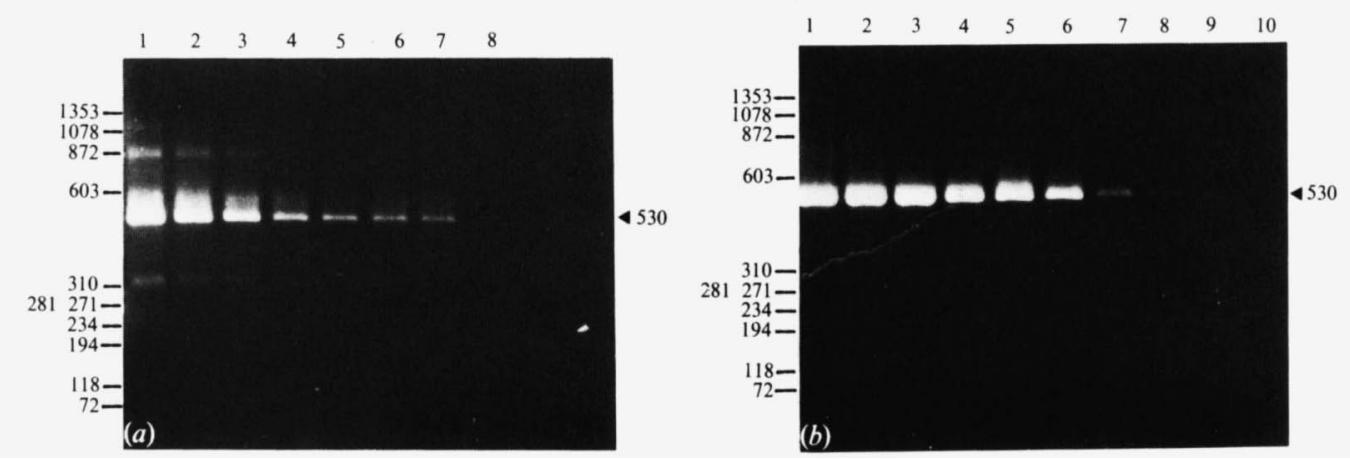

Fig. 2. Sensitivity of the PCR. PCR was performed with primer pair $\$ 13 /$ S62 as described in Methods. (a) Analysis of amplified DNA by electrophoresis on a $2 \%(w / v)$ agarose gel of samples with target DNA isolated from $100 \mu \mathrm{l}$ of 10 -fold sequential dilutions of a suspension of $M$. leprae containing $2 \times 10^{7}$ bacteria $\mathrm{ml}^{-1}$. The numbers of bacteria per sample were as follows: $2 \times 10^{6}$ (lane 1 ), $2 \times 10^{5}$ (lane 2), $2 \times 10^{4}$ (lane 3), $2 \times 10^{3}$ (lane 4), $2 \times 10^{2}$ (lane 5), $2 \times 10^{1}$ (lane 6), $2 \times 10^{\circ}$ (lane 7) and $2 \times 10^{-1}$ (lane 8). (b) Analysis of amplified DNA by electrophoresis on a $2 \%(w / v)$ agarose gel of samples which contained target DNA purified from $M$. leprae. A stock solution was diluted to give following amounts of DNA in the samples: $1 \mu \mathrm{g}$ (lane 1), $100 \mathrm{ng}$ (lane 2), $10 \mathrm{ng}$ (lane 3), $1 \mathrm{ng}$ (lane 4), $100 \mathrm{pg}$ (lane 5), $10 \mathrm{pg}$ (lane 6), $1 \mathrm{pg}$ (lane 7), $100 \mathrm{fg}$ (lane 8), $10 \mathrm{fg}$ (lane 9) and $1 \mathrm{fg}$ (lane 10). Numbers at left and right indicate sizes in bp.

bands at $200 \mathrm{bp}$ in the various samples (Fig. 1a) may be due to the presence of one or more mismatches between the primers and the corresponding regions of the target DNAs. Nevertheless, a fragment of approximately the same size was amplified from the DNA of each species tested. P1 and P2 are apparently located in a well-conserved region of the $65 \mathrm{~K}$ gene. In our case, primers $\mathrm{P} 1$ and $\mathrm{P} 2$ served as a useful internal control for the reaction conditions and might be useful as such in the testing of clinical samples. These experiments are now in progress.

\section{Sensitivity of the PCR}

The sensitivity of the PCR with primers S13 and S62 was determined by adding to the reaction mixtures DNA extracted from $0.1 \mathrm{ml}$ samples of sequential 10 -fold dilutions of a suspension containing $2 \times 10^{7}$ purified leprosy bacilli $\mathrm{ml}^{-1}$. Addition of DNA extracted from a $10^{6}$-fold dilution of the suspension (theoretically, two bacteria) could be amplified sufficiently, and reproducibly, to give a clearly detectable band in an agarose gel (Fig. $2 a$, lane 7). No band was detectable either on agarose gels (Fig. $2 a$, lane 8), nor on more sensitive Southern blots (not shown), when an extract was added from a suspension containing theoretically less than one bacillus. The accuracy of both the microscopic counting of the bacteria in the initial suspension, and the dilution thereof, are limited. Nevertheless, these results suggest that the detection limit of the PCR as performed here approximates 1 to 10 bacilli. A similar detection limit with PCR has been reported by Saiki et al. (1988).

In order to investigate further the sensitivity of the PCR, an additional experiment was performed in which various dilutions of purified $M$. leprae DNA were added to the reaction mixtures. Addition of $100 \mathrm{fg}$ chromosomal DNA resulted in a detectable band on agarose gels (Fig. 2b, lane 8), whereas no band could be seen when higher dilutions of DNA were added (Fig. $2 b$, lanes 9 and 10 ). Given that the size of the $M$. leprae genome is $2.2 \times 10^{9} \mathrm{Da}$ (Clark-Curtiss $e t$ al., 1985), $100 \mathrm{fg}$ of DNA corresponds to approximately 20 bacteria.

Thus, similar detection limits were found when DNA extracted from various numbers of $M$. leprae and various dilutions of DNA after purification were used. This indicates that the DNA extraction procedure is very efficient even on low numbers of $M$. leprae and that primers based on a single copy DNA are sufficient to detect only a few bacteria. This implies that the PCR described here is much more sensitive than other methods for the direct detection of $M$. leprae, such as microscopic visualization $\left(10^{5}-10^{6}\right.$ bacteria; Yaeger et al., 1966) and DNA hybridization (104 bacteria; Shoemaker et al., 1985; Clark-Curtiss, 1988; Eisenach et al., 1988). 


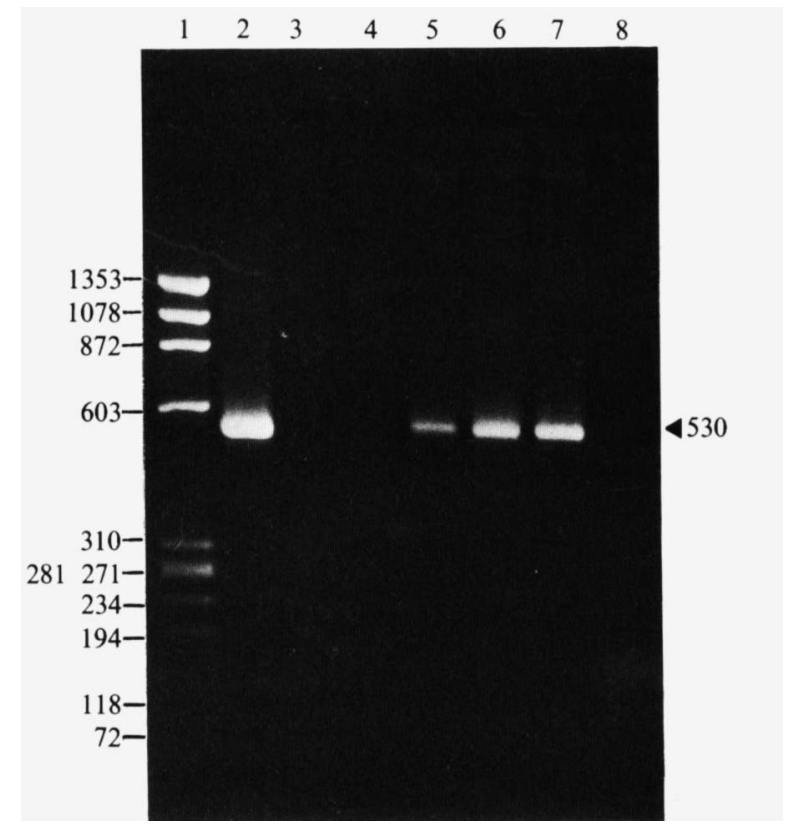

Fig. 3. Detection of $M$. leprae in armadillo liver tissue. PCR was performed with primer pair S13/S62 as described in Methods. Analysis of amplified DNA by electrophoresis on a $2 \%(w / v)$ agarose gel of samples which contained DNA extracted from $100 \mu \mathrm{g}$ of liver homogenate from uninfected armadillos (lane 3 and 4) and from experimentally-infected armadillos which contained $10^{7}$ (lane 5), $5 \times 10^{9}$ (lane 6) and $2 \times 10^{10}$ (lane 7) $M$. leprae ( $\mathrm{g}$ liver tissue ${ }^{-1}$ ) as determined by microscopic counting. Controls included $200 \mathrm{ng}$ purified $M$. leprae DNA (lane 2) and no DNA (lane 8). Lane 1 contained molecular size markers. Numbers at left and right indicate sizes in bp.

\section{Detection of $M$. leprae in armadillo liver tissue}

As an initial step to explore the use of the PCR on clinical samples, we have applied the PCR to liver homogenates of experimentally-infected armadillos.

PCR was done with target DNA extracted from $100 \mu \mathrm{g}$ of armadillo liver homogenates containing $10^{10}, 10^{9}, 10^{7}$ and 0 bacilli (the latter from uninfected animals) $\mathrm{g}^{-1}$, respectively, as determined by microscopic counting. As shown in Fig. 3, $M$. leprae could be detected in tissues from all three infected armadillos (lanes 5,6 and 7). No bands were visible in the samples from the two uninfected armadillos (lanes 3 and 4), indicating that the PCR as performed under these conditions did not result in the amplification of armadillo DNA in the sample. Even in the sample containing DNA from the lightly-infected armadillo $\left(10^{7} \mathrm{per} \mathrm{g}\right.$ liver $)$, a clear positive PCR signal was generated (Fig. 3, lane 5). This indicates that 1000 bacilli can easily be detected in tissues and that the enzymic lysis used (see Methods) is suitable for the extraction of target DNA from bacilli embedded in armadillo tissue and probably also in human tissue.

The armadillos used were infected with different isolates of $M$. leprae. This implies that the PCR described here is likely to be generally applicable and not restricted to the detection of a single isolate of $M$. leprae.

\section{Conclusions}

A method for the direct, specific, quick and reliable detection of $M$. leprae would permit epidemiological evaluation of the distribution of $M$. leprae in a population. In combination with treatment at an early stage of the disease, this strategy might prevent serious damage in patients, and eventually effectively break the transmission cycle. However, currently available methods to detect $\boldsymbol{M}$. leprae lack the required sensitivity. Here we have tested the PCR as a potential tool for the detection of $M$. leprae. Using primers based on a sequence of the $36 \mathrm{~K}$ gene, we were able to specifically detect purified $M$. leprae bacilli, as well as $M$. leprae in armadillo tissue. 
Considering that the detection limit approached one bacillus, this method may be suitable for the epidemiology of large numbers of people, as well as for clinical studies (diagnosis and followup) on individual patients and eventually for the control of leprosy.

We are obliged to Dr R. J. van Ketel for his gift of bacterial strains and H. M. Hodemaekers for the synthesis of the oligonucleotides. We thank Dr Jelle Thole, Dr Kees Verstijnen, Jannet van Leeuwen and Sjoukje Kuijper for their assistance in this study. We thank Dr Pamela Wright for critical reading of the manuscript.

This work was supported by the Netherlands Leprosy Relief Association and the Commission of the European Communities Directorate General for Science and Development TSD.004/333.

\section{REFERENCES}

Clark-Curtiss, J. E. (1988). Molecular relatedness among Mycobacterium leprae isolates defined using recombinant DNA probes (Abstracts of the 13th International Leprosy Congress '88). Health $\mathrm{Co}^{-}$ operation Papers 9, 125.

Clark-Curtiss, J. E., Jacobs, W. R., Docherty, M. A., Ritchie, L. R. \& CuRtiss, R. III (1985). Molecular analysis of DNA and construction of genomic libraries of Mycobacterium leprae. Journal of Bacteriology 161, 1093-1102.

Eisenach, K. D., Crawford, J. T. \& Bates, J. H. (1988). Repetitive DNA sequences as probes for Mycobacterium tuberculosis. Journal of Clinical Microbiology 26, 2240-2245.

van EYS, G. J. J. M., ZaAl, J., Schoone, G. J. \& TERPSTRA, W. J. (1988). DNA hybridization with hardjobovis-specific recombinant probes as a method for type discrimination of Leptospira interrogans serovar hardjo. Journal of General Microbiology 134, 567-574.

Fine, P. E. M., Ponnighaus, J. M., Burgess, P., Clarkson, J. A. \& Draper, C. C. (1988). Seroepidemiological studies of leprosy in Northern Malawi based on an enzyme-linked immunosorbent assay using synthetic glycoconjugate antigen. International Journal of Leprosy 56, 243-254.

HartSkeERl, R. A., SuYkerbuyk, M. E. G., Gupta, R. \& Thole, J. E. R. (1988). Selection of recombinant DNA clones expressing the $12 \mathrm{~K}$ and $36 \mathrm{~K} M$. leprae antigens in $E$. coli (Abstracts of the 13th International Leprosy Congress 88 ). Health $\mathrm{Co}^{-}$ operation Papers 9, 129.

KirChHeimer, W. F. \& StorRs, E. E. (1971). Attempts to establish the armadillo (Dasypus novemcinctus Linn.) as a model for the study of leprosy. International Journal of Leprosy 39, 693-703.

Kogan, S. C., Doherty, M. \& Gitschier, J. (1987). An improved method for prenatal diagnosis of genetic diseases by analysis of amplified DNA sequences. Application to hemophilia A. New England Journal of Medicine 317, 985-990.

Kolk, A. H. J., Ho, M. L., Klatser, P. R., Eggelte, T. A. \& Portaels, F. (1985). Production of monoclonal antibodies against Mycobacterium leprae and Armadillo-derived mycobacteria. Annales de l'Institut Pasteur 136B, 217-221.

Maniatis, T., Fritsch, E. F. \& Sambroox, J. (1982). Molecular Cloning: a Laboratory Manual. Cold Spring Harbor, NY: Cold Spring Harbor Laboratory.

Mehra, V., Sweetser, D. \& Young, R. A. (1986). Efficient mapping of protein antigenic determi- nants. Proceedings of the National Academy of Sciences of the United States of America 83, 70137017.

Mullis, K. B. \& Faloona, F. A. (1987). Specific synthesis of DNA in vitro via a polymerase-catalyzed chain reaction. Methods in Enzymology 155, 335-350.

OKANISHI, M. \& MANOME, T. (1980). Isolation and characterization of plasmid DNA in Actinomycetes. Journal of Antibiotics 33/1, 88-91.

Ou, C., KWoK, S., Mitchell, S. W., MaCK, D. H., SNinsky, J. J., Krebs, J. W., Feorino, P., WarFIELD, D. \& SCHOCHETMAN, G. (1988). DNA amplification for direct detection of HIV-1 in DNA of peripheral blood mononuclear cells. Science 239, 295-297.

PoRTAELS, F. \& PATTYN, S. R. (1982). Isolation of fastidiously growing mycobacteria from armadillo livers infected with Mycobacterium leprae. International Journal of Leprosy 50, 370-374.

Saiki, R. K., Scharf, S., Faloona, F., Mullis, K. B., Horn, G. T., ERlich, H. A. \& Arnheim, N. (1985). Enzymatic amplification of $\beta$-globin genomic sequences and restriction site analysis for diagnosis of sickle cell anemia. Science 230, 1350-1354.

SaIKI, R. K., Gelfand, D. H., Stoffel, S., Scharf, S. J., Higuchi, R., HoRN, G. T., Mullis, K. B. \& Ehrlich, H. A. (1988). Primer-directed enzymatic amplification of DNA with a thermostable DNA polymerase. Science $239,487-491$.

Shibata, D. K., ARnheim, N. \& Martin, W. J. (1988). Detection of human papilloma virus in paraffinembedded tissue using the polymerase chain reaction. Journal of Experimental Medicine 167, 225-230.

Shinnick, T. M., Sweetser, D., Thole, J., van EMBden, J. \& Young, R. A. (1987). The etiological agents of leprosy and tuberculosis share an immunoreactive protein antigen with the vaccine strain Mycobacterium bovis BCG. Infection and Immunity 55, 1932-1935.

Shinnick, T. M., Vodkin, M. H. \& Williams, J. C. (1988). The Mycobacterium tuberculosis 65-kilodalton antigen is a heat shock protein which corresponds to common antigen and to the Escherichia coli GroEL protein. Infection and Immunity 56, 446-451.

Shoemaker, S. A., Fisher, J. H. \& Scoggin, H. (1985). Techniques of DNA hybridization detect small numbers of mycobacteria with no cross-hybridization with nonmycobacterial respiratory organisms. Annual Review of Respiratory Diseases 131, 760763.

Southern, E. M. (1975). Detection of specific sequences among DNA fragments seperated by gel 
electrophoresis. Journal of Molecular Biology 98, 503-517.

ThOLE, J. E. R. (1988). A major immunogenic mycobacterial antigen: its molecular characterization and its implication in adjuvant arthritis. PhD Thesis, University of Amsterdam.

Thole, J. E. R., Keulen, W. C., Kolk, A. H. J., Groothuis, D. G., Berwald, L. G., Tietsjema, R. H. \& VAN EmbDEN, J. D. A. (1987). Characterization, sequence determination, and immunogenicity of a 64-kilodalton protein of Mycobacterium bovis BCG expressed in Escherichia coli. Infection and Immunity 50, 800-806.

Thole, J. E. R., Hindersson, P., DE Bruyn, J., Cremers, F., van der Zee, J., De Cock, H., Tommassen, J., van Eden, W. \& Van Embden, J. D. A. (1988). Antigenic relatedness of a strongly immunogenic $65 \mathrm{kDa}$ mycobacterial protein antigen with a similar sized ubiquitous bacterial common antigen. Microbial Pathogenesis 4, 71-83.

DE WIT, M. Y. L. \& KLATSER, P. R. (1988). Purification and characterization of a $36 \mathrm{kDa}$ antigen of Mycobacterium leprae. Journal of General Microbiology 134, 1541-1548.

Wong, C., Dowling, C. E., Saiki, R. K., Higuchi, R. G., Erlich, H. A. \& Kazazian, H. H. (1987). Characterization of $\beta$-thalassaemia mutations using direct genomic sequencing of amplified single copy DNA. Nature, London 330, 384-386.

World Health ORganization (1980). Purification of $M$. leprae. Report of the 5th meeting of the Scientific Working Group on the Immunology of Leprosy (IMMLEP). TDR/IMMLEP-SWG(5)/80.3. Geneva: World Health Organization.

World Health ORganization (1988). WHO Expert Committee on Leprosy: 6th Report. Technical Report Series, no. 768. Geneva: World Health Organization.

YAEGER, H. JR, LACY, J., SMith, L. R. \& Lemaister, C. A. (1966). Quantitative studies of mycobacterial populations in sputum and saliva. American Review of Respiratory Diseases 95, 998-1004. 